NBER WORKING PAPER SERIES

STRATEGIC INVESTMENT IN A DEBT BARGAINING FRAMEWORK

Joshua Aizenman

Eduardo Borensztein

Working Paper No. 3019

NATIONAL BUREAU OF ECONOMIC RESEARCH

1050 Massachusetts Avenue

Cambridge, MA 02138

June 1989

Joshua Aizenman and Eduardo Borensztein are affiliated with The Hebrew University at Jerusalem and NBER, and International Monetary Fund, respectively. This paper was written while Joshua Aizenman was consultant at the Research Department of the I.M.F. This paper is part of NBER's research program in International Studies. Any opinions expressed are those of the authors not those of the National Bureau of Economic Research. 
NBER Working Paper \#3019

June 1989

\section{STRATEGIC INVESTMENT IN A DEBT BARGAINING FRAMEWORK}

\section{ABSTRACT}

This paper analyzes the strategic role of investment from a debtor country's perspective. The framework is one in which, if the debtor country is unable to meet debt obligations, a bargaining regime determines the amount of debt repayment. In the context of a two-country real trade model, debt repayment is equal to the trade surplus of the debtor. The outcome of the bargaining game will therefore be dependent (among other things) on the level of production in the debtor country. In this framework, the paper shows that productive investment may increase or decrease the bargaining power of the debtor country. This ambiguity appears to be fairly robust.

Joshua Aizenman

Economics Department The Hebrew University

Mt. Scopus, Jerusalem 91905 Isreal
Eduardo Borensztein International Monetary Fund 700 19th Street, NW Washington, D.C. 20431 


\section{Introduction}

The purpose of this paper is to analyze the strategic role of investment in a debt situation that includes the possiblity of default and establishment of a bargaining regime in which debtor and creditor negotiate the amount of repayment. The recent literature has developed the notion of the debt overhang, which argues that old debt works as a tax on new investment. This effect follows from the assumption that creditors obtain a share in the proceeds from new investment, and this acts as an effective tax on new investment. This paper describes an environment in which, due to strategic considerations, the debt overhang generates ambiguous incentives over investment. In particular, we identify a case in which investment helps the debtor country to obtain a better outcome in the bargaining process. In this case, the debt overhang acts as a subsidy to investment.

The possibility of default by the debtor country introduces two separate effects. The first is the standard credit rationing effect. This means that the debtor country faces an upward-sloping credit supply and an overall ceiling on foreign debt, with the consequent increase in the domestic real interest rate and decrease in productive investment. Note that this effect is independent from and additional to the "debt tax" argument suggested by the debt overhang literature. The second is the strategic effect of partial defaults: the effect of an increase in investment on the outcome of the bargaining game for the debtor. The sign and magnitude of this effect depends on the 
characteristics of the bargaining game.

This paper shows that productive investment may either improve or worsen the bargaining outcome for the debtor, which implies that the debt overhang does not necessarily act as a tax on investment in this sense. To analyze the role of strategic investment, we start by describing the supply of credit facing the debtor in this context. The credit supply schedule incorporates the possibility of a bargaining regime, either as a random future event or as the current regime. Because the outcome of the bargaining process is determined (among other factors) by the capital stock of the debtor economy the supply schedule shifts with changes in investment in the debtor economy. $1 /$

When choosing its optimal capital accumulation, the debtor country considers the effects on the foreign debt situation. The debtor must weigh two effects: a direct effect on the amount of repayment (the outcome of the bargaining game), and an indirect effect on the cost of borrowing (the response of the credit supply function). The paper shows that the direct repayment effect always dominates. The reason is that a reduction in the cost of credit benefits the country only in the good states of nature, when the country chooses not to default, while a better bargaining outcome benefits the country in the bad states of nature, when it prefers to default on foreign

1) In a multiple-sector economy, the composition of the capital stock becomes critical. The foreign debt repercussions of investment allocation between sectors have been studied by Aizenman (1988), Borenstein and Ghosh (1989) and Diwan (1988). 
debt payments. Because the marginal utility of consumption and the marginal value of traded inputs are both higher in the bad states of nature, gains obtained in the bargaining regime are more valuable than gains obtained in the nondefault regime.

The change in the bargaining outcome as a response to investment in the debtor country is not uniquely determined and depends on the particular structure of international trade. Our basic framework is one in which trade takes place on primary productive inputs, while the final good (used for both consumption and investment) is non-tradable. International trade benefits are thus obtained from input diversification. In this context, the effect of investment depends on the substitutability between capital and traded inputs in the production function of the debtor country. If the elasticity of substitution of capital with traded inputs exceeds (falls short of) unity, an increase in investment increases (reduces) the repayment to the creditor. We confirm the robustness of this general result by analyzing an alternative international trade framework, which is a simplified two-country two-good trade model. In this case, the effect of investment on debt repayments depends on the specification of the utility functions and it may also be either positive or negative.

II. The supply of credit

We will initially assume that in the first period a free-trade regime exists because debt is not large enough for the debtors to 
default in its service and enter the bargaining situation. However, there is uncertainty concerning the second period, and there is some probability of default. If the debtor country can expect a better outcome by entering the bargaining game than by fully servicing its debt, it will default on its debt. For simplicity, we will assume that the only source of uncertainty is a random shock to the supply of the debtor country's primary input. There are two possible states of nature: a high-output state (positive supply shock) and a low-output state (negative supply shock). These states are indexed by $(H, L)$. Therefore, the supply of the debtor's primary product can take two values: $\overline{\mathrm{x}}^{\mathrm{H}}$ and $\overline{\mathrm{x}}^{\mathrm{L}}$.

Let $R$ denote the total payoff on foreign debt obtained by the creditor country in the second period. In this two-country world, $R$ is equal to the trade deficit run by the creditor country when trade flows are valuated at the free-trade prices. In the bargaining regime, two payoffs are possible according to the prevailing state of nature, which verify:

(1) $R^{H}>R^{L}$

because some of the extra output available in the high-output state will be received as debt repayment by the creditor. Though plausible, the above statement is not self-evident; however, it can be easily proved for the bargaining model described in the next section, which is done in the Appendix. 
We will assume that the creditor country behaves according to a maximum expected value rule. This implies that the creditor's supply curve will satisfy the following condition:

(2) $\left(1+r^{f}\right) B=E(R)$

where $r^{f}$ is the risk-free interest rate. Note that $R$ depends on the regime prevailing in the second period, that is, on whether there will be full repayment of debt or a bargaining outcome. Moreover, if the bargaining regime prevails, $R$ will be dependent on the state of nature. Therefore, $R$ can take three values: $(1+r) B, R^{H}$, and $R^{L}$, according to the regime at the time of repayment and to the state of nature, where $r$ represents the contractual interest rate charged on loans.

For given values of the state variables (the capital stocks in the debtor and creditor countries), the debt level may fall in three different regions giving rise to three different segments in the credit supply function: a horizontal segment, an upward-sloping segment, and a vertical segment. For very low values of debt, the debtor will prefer full payment to entering a bargaining situation. Let $\underline{B}$ denote the maximum debt level for which the debtor will choose not to bargain (in either state of nature) and will repay debts in full. That is, $\underline{B}$ will be given by:

(3) $(1+r) \underline{B}=R^{L}$ 
This means that at some low levels of debt it is cheaper for the debtor to meet its obligation in full than to enter the bargaining process, irrespective of the state of nature. Because the debtor would never choose to default, the risk-free interest rate $r^{f}$ will be charged for any debt level lower than or equal to $\underline{B}$.

In this framework, there is always a maximum amount of debt that creditors are willing to hold. The existence of this upper bound follows from the fact that there is a maximum payoff that can be obtained in the bargaining process $\left(\mathrm{R}^{\mathrm{H}}\right)$ and a larger loan will not increase that maximum payoff, irrespective of the contractual interest rate being charged. Assuming the high-output state and the low-output state both have the same probability of occurence, the maximum value of debt, which we denote $\bar{B}$, is obtained from:

(4) $\bar{B}\left(1+r^{f}\right)=.5\left(R^{L}+R^{H}\right)$

Any increase in $B$ beyond $\bar{B}$ does not increase the expected payoff; moreover, for any value of $B$ higher than $\bar{B}$ the creditors will obtain an expected return lower than the risk-free interest rate, independently of the contractual interest rate.

For loans larger than $\underline{B}$ but smaller than $\bar{B}$, we are in a situation in which the debtor would default and enter the bargaining equilibrium if the bad state occurs, but would repay in full in the good state. In this range, the supply curve will satisfy: 

$B\left(1+r^{f}\right)=.5\left(B(1+r)+R^{L}\right)$, or
(5) $1+r=2\left(1+r^{f}\right)-R^{L} / B, \quad \underline{B}<B<\bar{B}$

It is apparent that in this region $r$ is a positive function of $B$. Therefore, the shape of the supply curve will be as shown in Figure 1. We can also obtain the maximum contractual interest rate, $\bar{r}$ that will be charged on loans just equal to the maximum feasible, $\bar{B}$.

$$
1+\bar{r}=2\left(1+r^{f}\right)-R^{L} / \bar{B}
$$

which implies:

$$
1+\bar{r}=2\left(1+r^{f}\right)\left(1-\frac{R^{L}}{R^{L}+R^{H}}\right)
$$

Note that the position of the supply curve is a function of the second-period output in the debtor country, that is, of its capital stock and endowment shock. Being aware of that fact, the debtor country will adjust its investment strategy to take account of the repercussions on the credit supply function. Before turning to the debtor's decision, let us examine the changes in the supply function induced by investment in the debtor country. A change in the capital stock will affect all $\underline{B}, \bar{B}$, and $r(B)$ as follows:

(6) $\frac{\mathrm{dB}}{\mathrm{dK}^{*}}=\frac{1}{1+\mathrm{r}^{\mathrm{f}}}-\frac{\mathrm{dR}^{\mathrm{L}}}{\mathrm{dK}^{*}}$ 


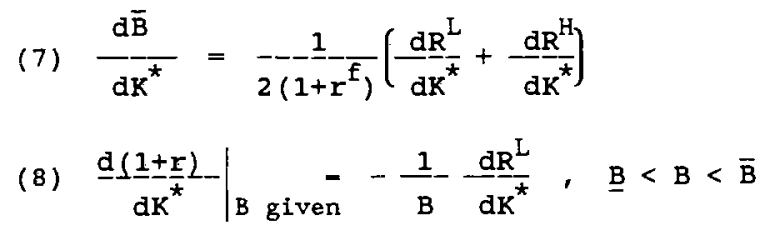

It is apparent that the direction of the shift in the supply curve is determined by the signs of how the payoffs are affected for creditors and debtors. As we showed in the bargaining equilibrium, two cases are possible. In the first, an increase in the capital stock of the debtor country increases the payoff for the creditor in both states of nature, which shifts the supply curve outwards. In the second case, an increase in the capital stock of the debtor country reduces the payoff for the creditor in both states of nature, which shifts the supply curve inwards.

Notice that so far we have assumed that there is no outstanding debt at the beginning of the first period. However, this is a generalization that can be made without much effort. Let $B_{0}$ be the previous outstanding debt and $R_{0}$ be the repayment in the first period, itself the outcome of bargaining between debtor and creditor. Then the new debt level that the creditor will be willing to hold must satisfy:

(9) $B \leq R_{0}-B_{0}+\frac{.5}{\left(R^{L}\right.} \frac{\left.+R^{H}\right)}{1+r^{f}}$

The supply schedule for this case is obtained simply by substituting $B+B_{0}-R_{0}$ in equation (5) for $B$. The financial 
operation in this case involves rolling over debt for an amount equal to $B_{0}-R_{0}$, and issuing new loans for an amount equal to $B$. The situation is depicted in Figure 2. We basically have the same supply curve as in Figure 1, but with a rightward shift in the origin of $B_{0}-$ $R_{0}$. The effect of the debt overhang is that the country starts with a new debt of $B_{0}-R_{0}$, and consequently the supply of new credit $B$ is reduced from ss to $s_{0} s$. But all the previous qualitative results are still valid. In particular, investment in the debtor country will still shift the supply curve in the ways described above.

\section{The Bargaining Equilibrium}

If the debtor country decides to completely default on its debts, it will suffer economic sanctions that would involve some disruption of its international trade. An extreme case is when trade is made completely impossible, and the debtor country must live under autarky conditions. This situation would clearly be an inferior one: debtors lose all gains from international trade, and creditors can collect none of the outstanding debt. Therefore, there exists a possibility of engaging in some form of international trade which would be mutually advantageous. Such arrangement would be one in which creditors receive some debt repayment, and the debtor country is allowed to enter international trade under some conditions. The bargaining equilibrium developed in this section describes the outcome 
of negotiations between the debtor and creditor under these circumstances.

The trade model that we use essentially follows Ethier's (1982) framework. The two countries have an endowment of a primary product, which is internationally tradable, and which, together with capital (we exclude labor for simplicity), is used to produce the final, nontradable product. The primary product of the debtor country is denoted as $X$, and the primary product of the creditor country is denoted as $Y$. The quantitites of the two primary products used in production will be denoted as $\mathrm{X}^{*}$ and $\mathrm{Y}^{*}$ for the debtor country and as $X$ and $Y$ for the creditor country. Thus, we have:

$$
\begin{aligned}
& \text { (10) } \mathrm{X}^{*}+\mathrm{y}^{*}=\overline{\mathrm{X}} \\
& \text { (11) } \mathrm{X}+\mathrm{Y}=\overline{\mathrm{Y}}
\end{aligned}
$$

For the purposes of this section we will assume a unit (exogenous) supply of each primary good: $\overline{\mathrm{X}}=\overline{\mathrm{Y}}=1$. The quantities of the final good produced in each country will be denoted by $\mathrm{z}^{*}$ and $\mathrm{z}$. These are given by the following production functions:

$$
\begin{aligned}
& \text { (12) } \mathrm{z}^{\star}=\left(\mathrm{K}^{\star^{\alpha}}+\left(\mathrm{x}^{\star^{\beta}}+\mathrm{y}^{\star^{\beta}}\right)^{\alpha / \beta}\right)^{1 / \alpha} \\
& \text { (13) } \mathrm{z}=\left(\mathrm{K}^{\alpha}+(\mathrm{X}+\mathrm{Y})^{\alpha}\right)^{1 / \alpha}
\end{aligned}
$$

where $-\infty<\alpha, \beta<1$. 
In this context, gains from trade are derived from increasing returns in production generated by input diversity. 1 / To gain in clarity, we are assuming that only the debtor country obtains gains from trade. Therefore, although a purely free trade equilibrium will not generate any productivity benefit for the creditor country, the bargaining equilibrium brings about some debt repayment and is therefore beneficial for the creditor economy. Note that, in a free-trade regime, the creditor country may obtain intertemporal gains from trade, derived from the ability to lend to or to carry out direct investment in the developing country.

In the present context, both countries can abandon all negotiations and produce and consume at their autarky levels. These are the "threat points" of debtor and creditor; therefore, any bargaining equilibrium must satisfy the constraint of being preferred to the autarky position by both parties. We will apply the symmetric Nash bargaining equilibrium framework (see Roth (1979), Binmore (1987, etc). This bargaining equilibrium can be obtained by finding the Pareto-optimal allocation that maximizes the product of gains from trade, that is, of moving from autarky to a Nash bargaining equilibrium. Letting $z_{N}$ denote the level of production under the Nash equilibrium, and $z_{A}$ denote the level of production under autarky, the bargaining equilibrium is the solution to the following problem.

1) In the case of several productive sectors, the value of $\beta$, which represents the elasticity of substitution between the different productive inputs plays a key role to distinguish opposing effects of investment on the bargaining outcome. 
(14) $\operatorname{Max}\left(\mathrm{z}_{\mathrm{N}}^{*}-\mathrm{z}_{\mathrm{A}}^{*}\right)\left(\mathrm{z}_{\mathrm{N}}-\mathrm{z}_{\mathrm{A}}\right)$

This framework assumes perfect contemporaneous information for both parties. $1 /$ Another full information framework that has been applied to the debt problem is one in which the two parties make a sequence of offers and counteroffers, while time spent in the process is costly because of time discounting and depreciation of the underlying product, such as in o'connell (1987) and Bulow and Rogoff (1988). The existence of a "perfect equilibrium" in the latter type of game has been shown by Rubinstein (1979). Although the Nash equilibrium is a static game, in which the demands from both parties are made simultaneously, Binmore (1987) has showed that the perfect equilibria approximate the Nash bargaining solution when the interval between demands is short. If the time discount rates of the two parties differ, the perfect equilibria approximate an asymmetric Nash bargaining equilibrium. $2 /$

The symmetry in the production function implies that both inputs will always be used in equal quantities for the debtor country in both the free-trade and the bargaining regimes. In a free trade regime the relative price of the two inputs will be unity, because they are

1) See Rotemberg (1988) for a foreign debt bargaining model with imperfect information.

2) The asymmetric Nash bargaining problem is solved by maximizing;

$$
\left(\mathrm{z}_{\mathrm{N}}^{*}-\mathrm{z}_{\mathrm{A}}^{\star}\right)^{\sigma}\left(\mathrm{z}_{\mathrm{N}}-\mathrm{z}_{\mathrm{A}}\right)^{1-\sigma}
$$

where $\sigma$ indicates the bargaining power. The objective function (14) is equivalent to the above one with $\sigma=1 / 2$. 
perfect substitutes in the creditor country production function, and this ensures that they are demanded in equal amounts by the debtor country. In the bargaining regime, because the equilibrium satisfies Pareto optimality two primary inputs must also be used in equal amounts by the debtor country. This implies $\mathrm{x}^{*}=\mathrm{y}^{*}$. Also, because we assume unit supplies, $\mathrm{X}+\mathrm{Y}=2\left(1-\mathrm{X}^{\star}\right)$. This implies that:

$$
\begin{aligned}
& \mathrm{z}_{\mathrm{N}}^{\star}=\left(\mathrm{K}^{\star^{\alpha}}+2^{\alpha / \beta} \mathrm{x}^{\alpha}\right)^{1 / \alpha} \\
& \mathrm{z}_{\mathrm{N}}=\left(\mathrm{K}^{\alpha}+2^{\alpha}\left(1-\mathrm{X}^{\star}\right)^{\alpha}\right)^{1 / \alpha} \\
& \mathrm{z}_{\mathrm{T}}^{\star}=\left(\mathrm{K}^{\star^{\alpha}}+1\right)^{1 / \alpha} \\
& \mathrm{z}_{\mathrm{T}}=\left(\mathrm{K}^{\alpha}+1\right)^{1 / \alpha}
\end{aligned}
$$

Therefore, the global resource allocation is entirely determined by $x^{*}$, and we can treat the bargaining process as simply the selection of the value of $x^{*}$ in order to:

(15) $\operatorname{Max}_{\mathrm{X}} \ln \left(\mathrm{H}^{*^{1 / \alpha}}-1\right)+\ln \left(\mathrm{H}^{1 / \alpha}-1\right)$ with $\mathrm{H}^{\star}=\frac{\mathrm{K}^{\star^{\alpha}}+2^{\alpha / \beta} \mathrm{x}^{\star^{\alpha}}}{\mathrm{K}^{\star^{\alpha}}+1} ; \mathrm{H}=\frac{\mathrm{K}^{\alpha}+2^{\alpha}\left(1-\mathrm{x}^{\star}\right)^{\alpha}}{\mathrm{K}^{\alpha}+1}$

The first-order condition for this maximization is:

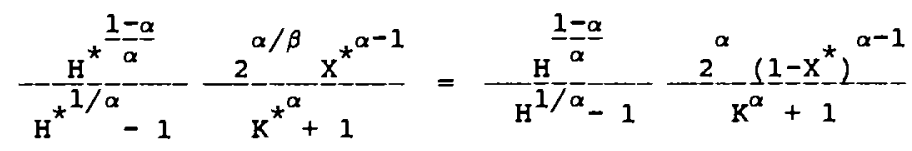


We are interested in the sign of $\mathrm{dx}^{*} / \mathrm{dk}^{*}$, because that derivative will determine investment decisions prior to the negotiation process. If $\mathrm{dx}^{\star} / \mathrm{dr}^{*}$ is negative, investment has the negative (for the debtor) side effect of increasing debt repayments, which reduces incentives to invest. We can identify this situation with the "debt overhang" problem.1/ By conträst, ${ }^{\star}$ if $\mathrm{dx} / \mathrm{dK}$ is positive, investment helps the debtor country to obtain a more favorable outcome from the bargaining, and the existence of large or nonserviceable debt has in fact a positive incentive effect for investment and production. In the Appendix, we show that the sign of $\mathrm{dx}^{*} / \mathrm{dk}^{*}$ is equal to minus the sign of $\alpha$. Note that the elasticity of substitution between capital and primary inputs is equal to $1 /(1-\alpha)$. Therefore, $\mathrm{dx}^{\star} / \mathrm{dk}^{\star}$ is positive when the elasticity of substitution is less than one, zero when the elasticity of substitution is equal to one, and negative when the elasticity of substitution is greater than one.

To gain further insight into this result let us denote by $T G\left(X^{\star}\right)$ and $\mathrm{TG}^{\star}\left(\mathrm{X}^{\star}\right)$ the gains from trade relative to autarky (in percentage terms) for the creditor and the debtor (for a given $x^{*}$ ). That is, TG and $\mathrm{TG}^{\star}$ are given by:

(17) $\mathrm{TG}^{\star}\left(\mathrm{X}^{\star}\right)=\mathrm{H}^{{ }^{1 / \alpha}}-1$
(18) $\mathrm{TG}\left(\mathrm{X}^{\star}\right)=\mathrm{H}^{1 / \alpha}-1$

1) See Dooley (1986), Froot (1988), Krugman (1988), Sachs (1987). 
Therefore, we can represent the condition defining the bargaining outcome (16) by the requirement that:

(19) $\mathrm{TG}^{*},\left(\mathrm{x}^{\star}\right) / \mathrm{TG}^{*}\left(\mathrm{x}^{\star}\right)=-\mathrm{TG}^{\prime}\left(\mathrm{x}^{*}\right) / \mathrm{TG}\left(\mathrm{x}^{*}\right)$

The right-hand side measures the percentage decrease in the creditor's gains from trade that is associated with a marginal increase of $x^{*}$, and is described by schedule CC in Figure 3. The left-hand side measures the percentage gain in the debtor's gains from trade associated with a marginal increase in $x^{*}$, and is described by schedule $\mathrm{DD}$. The intersection of both schedules gives the bargaining outcome. At this allocation a marginal change of $x^{*}$ will cause percentage losses of the gains from trade to one party that equal the percentage gains to the other party. Note that investment by the debtor will affect the DD schedule, and the resultant bargaining equilibrium.

To trace the consequences of the investment on the DD schedule one should evaluate both the change in the marginal and the average gains from trade i.e., the $\mathrm{TG}^{*},\left(\mathrm{x}^{*}\right)$ and the $\mathrm{TG}^{*}\left(\mathrm{x}^{*}\right)$, respectively. Direct derivation reveals that investment will reduce (increase) the marginal gains from trade $\left(\mathrm{TG}^{*},\left(\mathrm{X}^{*}\right)\right)$ if the elasticity of substitution between capital and the aggregate inputs exceeds (falls short of) unity, and will stay intact if the elasticity equals unity. It turns out that these factors dominate the behavior of the DD curve, which will shift downward (upward) for the elastic (inelastic) case. The unitary elasticity case is the borderline case, where the (percentage) 
gains from trade are independent from the aggregate capital stock, due to the multiplicative nature in which capital enters the production process.

Figure 3 is also useful to highlight the role of stochastic endowments. Note that a rise in the total endowment of the debtor will have the consequence of widening the bargaining region, and shifting curve $C C$ horizontally by the increase in endowment to $C^{\prime} C^{\prime}$. The bargaining outcome will increase by less than the endowment increase, making both the debtor and the creditors better off.

\section{The Debtor's Problem}

The debtor country faces the problem of choosing consumption and investment in a forward-looking way. In addition to standard optimality considerations, the debtor country will choose the level of investment that positions it advantageously for the bargaining game (if it were to take place.) Recall that we work with a two-period framework, where in the first period a free-trade regime prevails, but in the second either the free-trade or the bargaining regime may prevail.

As discussed in the bargaining section, in equilibrium the debtor uses the two intermediate goods in equal amounts. Let $\mathrm{V}$ indicate the composite of the intermediate goods $X$ and $Y$ used by the debtor country. Let $\bar{X}^{S}$ denote the supply of primary input $X$ in state $S$, for 
$S=$ H,L. The world supply of intermediate goods is then given by $(1,1)$ in the first period, and by $\left(\bar{x}^{S}, 1\right)$ in the second. Then, it can be seen that in a free trade regime, $V$ will be given by:

$$
\text { (20) } \mathrm{V}^{\mathrm{F}}-\overline{\mathrm{X}}-(1+\mathrm{r}) \mathrm{B}
$$

In the bargaining regime, $v$ will be given by:

(21) $v^{B}=\bar{x}-R=\bar{x}-\left(\bar{x}-2 x^{*}\right)=2 x^{\star}$

where $x^{\star}$ is the amount of input $x$ obtained by the debtor in the bargaining equilibrium. The repayment to the creditor is defined (in terms of the primary good composite) as the difference between the debtor's endowment $\bar{x}$ and what it keeps when the bargaining equilibrium is reached $\left(2 x^{*}\right)$. $1 /$

Using the composite $\mathrm{V}$ together with capital $\mathrm{K}^{\star}$ to produce output $z$, the debtor determines its consumption and investment decisions on the basis of the solution to the following problem:

$$
\begin{aligned}
\operatorname{Max} u\left(C_{1}\right) & +\operatorname{Eu}\left(C_{2}\right) \\
\text { s.t. } C_{1} & +I=z\left(K_{0}^{\star}, v_{0}+B\right) \\
C_{2} & =\max \left(z\left(K^{\star}, \bar{x}^{S}-B(1+r)\right) ; z\left(K^{\star}, \bar{x}^{S}-R^{S}\right)\right) \\
K^{*} & =I+K_{0}^{*}
\end{aligned}
$$

1) Recall that at the free-trade price of the two inputs is unity and the debtor country always uses the two inputs in equal quantities. 
where $C$ stands for consumption, I for investment and $z$ for production of the final good. $K_{0}^{*}$ and $v_{0}$ are the exogenously given initial stocks of capital and of the intermediate good composite, $B$ is the level of borrowing carried out in the first period, $R$ is the repayment obtained by the creditor country in the bargaining regime. International debt $B$ is denominated in units of the traded goods (that is, inputs). In the more general case of a starting debt overhang, $B-\left(B_{0}-R_{0}\right)$ takes the place of $B$ in the above system. In this two-period framework, we abstract from time preference in the utility function without loss of generality.

Given the shape of the credit supply function, there are three different situations that may arise. In the first case, $B<\underline{B}$, and the country can borrow as much as it wants at the fixed risk-free interest rate. In this situation, we can rewrite the problem as:

$\max _{I, B} u\left(z\left(K_{0}^{*}, v_{0}+B\right)-I\right]+.5 u\left(z\left(K^{*}, \bar{x}^{H}-B\left(1+r^{f}\right)\right)\right)+.5 u\left(z\left(K^{*}, \bar{x}^{L}-B\left(1+r^{f}\right)\right)\right)$

In this situation, standard intertemporal conditions for debt and investment will hold:

(23)

$$
\frac{E\left(u^{\prime}\left(c_{2}\right) Z_{K^{*}}\right)}{\lambda_{2}}=\frac{\lambda_{1}}{\lambda_{2}}
$$

$$
\frac{1+\underline{r}^{f}}{\lambda_{2}} \frac{E\left(u^{\prime}\left(c_{2}\right) z_{v}\left(K^{*}, \bar{x}_{1}^{S}-B(1+r)\right)\right)}{z_{v}\left(K_{0}^{*}, v_{0}+B\right)}=\frac{\lambda_{1}}{\lambda_{2}}
$$

where $\lambda_{1}=u^{\prime}\left(c_{1}\right)$, and $\lambda_{2}=E\left(u^{\prime}\left(c_{2}\right)\right)$. 
The first-order necessary conditions are the standard ones in stochastic models of intertemporal consumption. They equalize the covariances with the marginal utility of consumption of the returns on the different assets. Equation (23) applies this condition to domestic capital and the equation (24) applies it to foreign debt. Note that debt is denominated in traded input units and therefore the rate of change in its implicit relative price with consumption good is part of its return.

In the second regime, the upward-sloping section of the supply curve, the country will default in the bad state and repay in the good state. We can rewrite the problem as:

$\max _{I, B} u\left(z\left(K_{0}^{*}, V_{0}+B\right)-I\right]+.5 u\left[z\left(K^{*}, \bar{x}^{H}-B\left(1+r\left(B, K^{*}\right)\right)\right]+.5 u\left(z\left(K^{*}, \bar{x}^{L}-R^{L}\right)\right)\right.$ which yields the first order conditions:

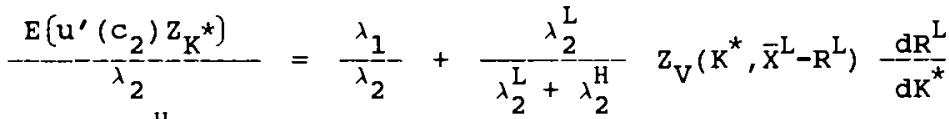

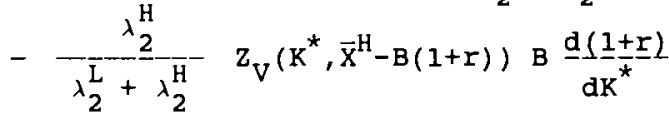

$$
\frac{\lambda_{2}^{\mathrm{H}}}{\lambda_{2}^{\mathrm{L}}+\lambda_{2}^{\mathrm{H}}}\left(\mathrm{l}+\mathrm{r}+\mathrm{B} \frac{\mathrm{dr}}{\mathrm{dB}}\right) \frac{\mathrm{Z}_{\mathrm{V}}\left(\mathrm{K}^{*}, \overline{\mathrm{X}}^{\mathrm{H}}-\mathrm{B}(1+\mathrm{r})\right)}{\mathrm{Z}_{\mathrm{V}}\left(\mathrm{K}_{0}, \mathrm{v}_{0}+\mathrm{B}\right)}=\frac{\lambda_{1}}{\lambda_{2}}
$$

where $\lambda_{2}^{\mathrm{H}}=u^{\prime}\left(c_{2}^{\mathrm{H}}\right), \lambda_{2}^{\mathrm{L}}=u^{\prime}\left(c_{2}^{\mathrm{L}}\right)$, and $\lambda_{2}=.5\left(\lambda_{2}^{\mathrm{H}}+\lambda_{2}^{\mathrm{L}}\right)$. Making use of (8), we can rewrite equation (25) as: 
(27) $\frac{\mathrm{E}\left(\mathrm{u}^{\prime}\left(\mathrm{C}_{2}\right) \mathrm{Z} \mathrm{K}^{\star}\right]}{\lambda_{2}}=\frac{\lambda_{1}}{\lambda_{2}}+\mathrm{A}-\frac{\mathrm{dR}}{\mathrm{dK}} \overline{\mathrm{K}}^{\mathrm{L}}$, where

$A=\frac{\lambda_{2}^{L}}{\lambda_{2}^{L}+\lambda_{2}} \mathrm{z}_{\mathrm{V}}\left(\mathrm{K}^{\star}, \overline{\mathrm{X}}^{\mathrm{L}}-\mathrm{R}^{\mathrm{L}}\right)-\frac{\lambda^{\mathrm{H}}}{\lambda_{2}^{\mathrm{L}}+\lambda_{2}^{\mathrm{H}}} \mathrm{z}_{\mathrm{V}}\left(\mathrm{K}^{\star}, \overline{\mathrm{X}}^{\mathrm{H}}-\mathrm{B}(1+\mathrm{r})\right)$

Condition (27) equates the expected marginal product of capital (measured in utility terms) with the sum of the benchmark domestic interest rate $\left(\lambda_{1} / \lambda_{2}\right)$ and the expected strategic effect of investment. The strategic effect of investment is given by the change in repayment in the bargaining regime $\left(\mathrm{dR}^{\mathrm{L}} / \mathrm{dK}^{\star}\right)$ weighted by the term $\mathrm{A}$, which measures the loss derived from a marginal increase in repayment in the bad state, and is defined by the difference between two terms. The first term is the effect of the change in the availability of traded inputs in the bargaining regime (measured in utility units), and the second is the change in the availability of traded inputs in the free-trade regime as a consequence of the shift in the supply curve. Notice that $A$ is always positive because both the marginal utility of consumption and the marginal product of inputs are higher in the lower output state. Therefore, the effect of investment on the repayment in the bargaining regime is always the dominant one.

Comparing (27) to (23) it is easy to see that strategic considerations affect the optimal value of the expected marginal product of capital in two ways: the change in bargaining repayment and the credit supply response. These two effects are always of opposite sign because if the change in repayment favors the debtor it must hurt 
the creditor, which prompts a credit supply response that increases the cost of borrowing. But, as we have shown $A$ to be positive, the direct repayment effect always dominates the indirect credit supply response.

Therefore, the strategic effect of investment depends on the change induced in bargaining power. If investment decreases the bargaining power of the debtor by increasing the debt repayment $\left(\mathrm{dR}^{\mathrm{L}} / \mathrm{dK}^{\star}>0\right)$, the strategic effect will reduce investment (because it implies that a higher marginal product of capital is optimal.) This is true despite the fact that the debtor country could improve its borrowing conditions by increasing investment spending because the repayment effect is more powerful. This situation matches the description of debt overhang models, in which past accumulated debts act as a tax on new investment. By contrast, when investment increases the bargaining power of the debtor $\left(\mathrm{dR}^{\mathrm{L}} / \mathrm{dK}^{*}<0\right)$, new investments generate a positive externality on the debt situation of the country, and the strategic incentives will work toward an increase in investment spending. In this case, paradoxically, an increase in investment spending by the debtor makes creditors less willing to lend by increasing the risk of default. $1 /$

One should be cautious, however, in deriving conclusions from the strategic positive incentive case. In particular, it does not imply that investment will be higher than in a case of absence of foreign

1/ Notice, however, that increases in the cost of borrowing by themselves do affect negatively the amount of foreign debt the country would like to have (see equation $(26)$.) 
debt (or more precisely of absence of constraints on foreign borrowing). This is because the fact that the debtor country faces an upward-sloping credit supply function implies that the benchmark domestic interest rate $\left(\lambda_{1} / \lambda_{2}\right)$ will be higher than in the case of no constraints on foreign borrowing, and investment is correspondingly lower. In our framework the absence of constraints on foreign debt exist at low levels of indebtedness, when there is no immediate risk of default $(B<\underline{B}$.

In the third possible case, the country has run up against the maximun amount of borrowing it can get, $\vec{B}$. At that point, a bargaining regime will take place for sure in the second period. The problem can then be formulated as:

$\max _{I} u\left(z\left(K_{0}^{*}, v_{0}+\bar{B}\right)-I\right]+.5 u\left(z\left(K^{*}, \bar{x}^{H}-R^{H}\right)\right]+.5 u\left(z\left(K^{*}, \bar{x}^{L}-R^{L}\right)\right]$

The first order condition for investment is:

$$
\frac{E\left(u^{\prime}\left(c_{2}\right) z_{K^{*}}\right)}{\lambda_{2}}=\frac{\lambda_{1}}{\lambda_{2}}+\frac{1}{\lambda}-E\left(\lambda_{2} z_{V}\left(K^{*}, \bar{x}^{S}-R^{S}\right)-\frac{d R^{s}}{d K^{*}}\right)
$$

Again, strategic considerations affect the investment decision. The bargaining regime implies that investment is "taxed" if the repayment increases with the stock of capital in the debtor country, but it is "subsidized" in the opposite case. Note that, in this second case, the existence of a large stock of previous debt implies that the country will be credit rationed, and the benchmark domestic 
interest rate $\left(\lambda_{1} / \lambda_{2}\right)$ will be much higher, which by itself depresses investment.

\section{An Alternative Bargaining Equilibrium}

In the bargaining model of section II, the effect of a larger capital stock on the payoff for the debtor depended on the elasticity of substitution in production, in the context of a diversified input trade model. However, the indeterminacy of the effect of higher capital (or output) on the bargaining payoff appears to be fairly robust. In this section we provide another example in which trade takes place in final goods (there are no primary inputs) and the same indeterminacy holds.

We assume that there are two final goods in the world economy: good D produced by the debtor country, and good F, produced by the creditor country. The two goods are perfect substitutes for the creditor country, while the debtor country has a preference for good F. More precisely, the utility function of the debtor country is given by:

(29) $\mathrm{u}=\mathrm{u}(\mathrm{D}+\alpha \mathrm{F})$

where $\alpha>1$, and the utility function of the creditor country is given by: 
(30) $v=v(D+F)$

The above utility functions imply that in a free-trade regime the relative price of the two goods is unity and the debtor country exports all of its output (we will assume throughout that $F>D_{0}$ ) The asymmetric framework implies that only the debtor country obtains gains from trade. But the creditor country needs to engage in international trade in order to extract any debt payments from the debtor country. The only way for the debtor country to make debt repayments is to run a trade surplus. 1

By definition, debt repayments are equal to the trade surplus of the debtor economy. Denoting debt repayments by $\mathrm{R}$ :

$$
\text { (31) } R=D-F^{E}
$$

where $F^{E}$ represents exports of the good $F$. Equivalently, we can assume that in the bargaining regime the two sides negotiate over terms of trade $x$, such that:

(32) $\times D=F^{E}$

where one unit of the $D$ good is exchanged for $x$ units of the $F$ good. $A$ value of $x$ less than one implies that positive debt repayments are

1/ Note that although the creditor country does not obtain static gains from trade, it may obtain intertemporal gains from trade by being able to decouple domestic savings and investment. But we abstract from this latter effect in this analysis. 
taking place. The bargaining equilibrium will consist in obtaining the value of $x$ that represents the outcome of the symmetric power negotiations between debtors and creditors.

The equilibrium value of $x$ has to satisfy two restrictions. First, $x$ must be less than one, because the creditor will never accept an offer that involves a value of $x \geq 1$, since such a value of $x$ implies a net transfer to the debtor and the creditor would be better off simply by breaking off negotiations. That is, $x=1$ is the creditor's "threat point". And second, $x$ must be larger than $1 / \alpha$ because otherwise the debtor country would be better off by breaking off negotiations and consuming its own output in autarky. Therefore, the debtor's threat point is $x=1 / \alpha$.

With $x$ lying in the above range, creditors buy as much of the $D$ good as they can get, and debtors buy as much F good as they can afford. Therefore, since we assume that $F>D>x D$, in the bargaining equilibrium, the creditor country consumes all the output of good $D$ and part of the output of good F. Thus, the consumption bundle (D,F) obtained by the debtor country is given by $(0, x D)$, and the consumption bundle obtained by the creditor country is given by (D,F-XD).

The Nash bargaining equilibrium for this game can be obtained by solving the following maximization problem:

$$
\begin{gathered}
\operatorname{Max}_{x}\left(u(D, F)-u^{A}(D, F)\right)\left(v(D, F)-v^{A}(D, F)\right) \\
\text { s.t. } 1 / \alpha<x<1
\end{gathered}
$$


where $u^{A}(.,$.$) and v^{A}(.,$.$) indicate the utility functions at the$ autarky consumption bundles. The first-order necessary condition is:

$$
u_{x}\left(v-v^{A}\right)=-v_{x}\left(u-u^{A}\right)
$$

for $x$ in the specified range. In light of the above description of the trades that take place in the bargaining regime and of (29) and (30), we can be more specific about the utility functions:

$$
\begin{aligned}
& \mathrm{u}=\mathrm{u}(\alpha \times D) ; \mathrm{u}^{\mathrm{A}}=\mathrm{u}(\mathrm{D}) \\
& \mathrm{v}=\mathrm{v}((1-\mathrm{x}) \mathrm{D}+\mathrm{F}) ; \mathrm{v}^{\mathrm{A}}=\mathrm{v}(\mathrm{F})
\end{aligned}
$$

We are interested in examining how the bargaining outcome is affected by a change in the endowment of the debtor country, that is, in the sign of $\mathrm{dx} / \mathrm{dD}$. This is the relevant relation for investment incentives. If $\mathrm{dx} / \mathrm{dD}$ is negative, a larger output in the debtor country increases the share of it going to the creditor in the bargaining outcome. In this case, we are in the presence of a "debt overhang" situation in which incentives to investment by the debtor country are reduced because of the larger transfer of resources to creditors in the event that a bargaining situation should arise in the future. By contrast, if $d x / d D$ is positive, the total return to investment for the debtor increases because of the positive effect of larger output on the payoff obtained by the debtor in case of bargaining. 
The sign of $\mathrm{dx} / \mathrm{dD}$ cannot be determined a priori. Two contradictory forces are present. One the one hand, a larger value of $D$ increases the threat point of the debtor, which is the minimum payoff it could obtain, thus contributing to a more favorable outcome for the debtor country. But on the other hand, if the increase in $D$ implies that the marginal gain from a change in payoffs increases more for the debtor than the creditor, the final outcome will be more favorable to the creditors.

The precise expression for $d x / d D$ is the following:

(34) $-\frac{d x}{d D}-=-\frac{u_{x D}\left(v-v^{A}\right)+u_{x} v_{D}+u_{D} v_{x}+v_{x D}\left(u-u^{A}\right)-v_{x} u_{D}^{A}}{u_{x x}\left(v-v^{A}\right)+2 u_{x} v_{x}+v_{x x}\left(u-u^{A}\right)}$

where the following relations hold:

$$
\begin{aligned}
& u_{x}=\alpha D u_{C}>0 \\
& u_{x x}=(\alpha D)^{2} u_{C C}<0 \\
& u_{D}=\alpha x u_{C}>0 \\
& u_{x D}=\alpha\left(u_{C}+\alpha x D u_{C C}\right) \gtrless 0 \\
& v_{x}=-D v_{C}<0 \\
& v_{x x}=D^{2} v_{C C}<0 \\
& v_{D}=(1-x) v_{C}>0 \\
& v_{x D}=-\left(v_{C}+(1-x) D v_{C C}\right) \gtrless 0
\end{aligned}
$$


By using the above relationships, it can be seen that the denominator of (34) is always negative. The numerator of (34) is, in principle, indeterminate, and it can be shown that it is equal to the following expression:

$$
\text { (35) } \alpha D u_{C} v_{C}\left(1-2 x+\frac{u}{\alpha}-\frac{u^{A}}{u_{C}}\left(-\frac{(1-x)}{(1-x)} \frac{D}{D}+\frac{F}{F}-\rho_{v}-\rho_{u}\right)+\frac{u_{C}^{A}}{\alpha u_{C}}\right)
$$

where $\rho$ represents the elasticity of marginal utility of the corresponding function, i.e.:

$$
\rho_{\mathrm{u}}=-\frac{\mathrm{u}_{\mathrm{CC}} \mathrm{C}}{\mathrm{u}_{\mathrm{C}}}, \quad \rho_{\mathrm{v}}=-\frac{\mathrm{v}_{\mathrm{CC}} \mathrm{C}}{\mathrm{v}_{\mathrm{C}}}
$$

The sign of (35) depends on the specific form of the utility function of the debtor and creditors. If both parties have logarithmic utility functions, it can be shown that (35) is positive. By contrast, when both parties have exponential utility functions, numerical simulation suggests that the sign is always negative. For example, using $u=v=-e^{-C}$, numerical solutions to the problem generate the following results:

\begin{tabular}{cccc}
$a$ & $\mathrm{D}$ & $\mathrm{x}$ & $\mathrm{dx} / \mathrm{dD}$ \\
\hline 2 & 1 & 0.74 & -0.01 \\
5 & 1 & 0.49 & -0.07 \\
2 & 3 & 0.74 & -0.007 \\
5 & 3 & 0.49 & -0.02
\end{tabular}


It is important to notice that, even when $d x / d D$ is negative, the debtor country is never worse off by having a larger supply of its output. In other words, du/dD is always positive. 1 / Therefore, even in the case that an increase in the debtor country's output generates an increase in debt repayment, the latter increase is never large enough to leave the debtor country in a less favorable position. This fact is reassuring, because otherwise the debtor country could make itself better off by destroying part of its output, and the bargaining equilibrium would not be well characterized.

VI. Conclusions

Our examples lead us to conclude that the strategic consequences of investment are rather involved and cannot be determined without detailed knowledge of the economy. The possibility that an actual or potential movement into a bargaining regime can either encourage or discourage investment for strategic reasons appears to be quite general. This result qualifies the arguments for a debt overhang disincentive effect on investment. But, once again, it should be stressed that the strategic effects are additional to the disincentive to investment caused by an upward-sloping credit supply curve and credit rationing.

1 Note that $\frac{d u}{d D}=u_{C} \alpha x\left(1+x \frac{d x}{d D}\right)$, and from (34) we get that $1+x \frac{d x}{d D}>0$. 
Another important aspect of the problem, which we did not touch in this paper, is the effect of the sectoral composition of investment. In this case, investment has a predictable effect: investment that increases the weight of the sector that is more (less) trade dependent will generate the strategic tax (subsidy) effect (see Aizenman (1988)). This suggests that greater attention should be given to the sectoral composition of investment in any attempt to 1 ink the availability of new credit and investment.

An important policy implication of this paper is that one cannot count on initiatives that reduce the burden of past debts to automatically improve incentives for investment in indebted countries. This may be the case for certain countries but does not necessarily hold for all. More generally, one would expect that, for strategic reasons, the debt overhang depresses certain types of investment and encourages others. Although this situation would not be an optimal resource allocation in a free trade, no risk of default regime, it may still be the case that, for some countries, the depression of investment is more closely related to a shortage of savings generated by international credit constraints and low domestic savings. In this case, for example, policies that encourage domestic savings would have a much larger impact on domestic investment than a change in the incentive structure arising from the debt overhang.

Our analysis suggests that the consequences of the debt overhang for aggregate investment may be ambiguous in value. For example, a rise in investment triggered by strategic considerations may in fact 
reflect an attempt by the debtor country to increase its future bargaining power, and will result in lower repayments. A related example would be an increase in international reserve holdings by the debtor country. Therefore, factors such as the composition of investment may provide a better signal about prospects for future repayment. 
Appendix

1. The Effect of the Capital stock on the Bargaining outcome

In order to determine the change in the bargaining outcome, we can assume $\mathrm{K}$ parametrically fixed and express equation (16) as:

(a1) $f\left(k^{*}, x^{*}\right)=g\left(x^{*}\right)$

so that:

$$
\text { (a2) }-\frac{d x^{*}}{d K^{*}}=-\frac{f_{K^{*}}}{g_{X}^{*}-f_{X}^{*}}
$$

It can be shown that $g_{X}{ }^{*}>0$ and $f_{X} *<0$, so that the sign of $\frac{d x^{*}}{d K^{*}}$ is the same as the sign of $f_{K}^{*}$. And the sign of $f_{K} *$ is the negative of the sign of $\alpha$. We will prove each one of these statements now.

1. $g_{X} *>0$

$$
\begin{aligned}
g_{\mathrm{X}}{ }^{*}= & c\left(\mathrm{H}^{1 / \alpha}-1\right)\left(-(1-\alpha) \mathrm{H}^{\frac{1-2 \alpha}{\alpha}} 2^{\alpha} \frac{\left(1-\mathrm{x}^{\star}\right)^{2 \alpha-2}}{\mathrm{~K}^{\alpha}+1}-\mathrm{H}^{\frac{1-\alpha}{\alpha}}(\alpha-1)\left(1-\mathrm{X}^{*}\right)^{\alpha-2}\right)+ \\
+ & \left.\mathrm{H}^{\frac{2-2 \alpha}{\alpha}} 2^{\alpha} \frac{\left(1-\mathrm{x}^{*}\right)^{2 \alpha-2}}{\mathrm{~K}^{\alpha}+1}\right)
\end{aligned}
$$

where $C$ is a positive constant equal to $-\frac{\alpha^{\alpha}}{\left(\mathrm{K}^{\alpha}+1\right)\left(\mathrm{H}^{1 / \alpha}-1\right)^{2}} \cdot \operatorname{Recalling}$ that $\mathrm{H}^{1 / \alpha}>1$ always, it can be seen that the only negative term is the first term in the algebraic sum, but that it is dominated by the 
third term in the sum because:

$$
\begin{aligned}
& \mathrm{H}^{\frac{2-2 \alpha}{\alpha}} 2^{\alpha}\left(1-\mathrm{X}^{*}\right)^{2 \alpha-2}>(1-\alpha) \mathrm{H}^{\frac{1-2 \alpha}{\alpha}} 2^{\alpha}\left(1-\mathrm{X}^{*}\right)^{2 \alpha-2}\left(\mathrm{H}^{1 / \alpha}-1\right) \text {, or } \\
& \alpha \mathrm{H}^{1 / \alpha}>-(1-\alpha)
\end{aligned}
$$

2. $f_{x} *<0$

This is immediate from the above result. First note that, for $\mathrm{K}^{*}=\mathrm{K}, \mathrm{f}\left(\mathrm{x}^{*}\right)$ can be written as $\mathrm{g}\left(\mathrm{h}\left(\mathrm{x}^{*}\right)\right)$, with $\mathrm{h}_{\mathrm{X}^{*}}<0$. And second, note that changes in the value of $k$ do not change the sign of $g_{X}{ }^{*}$.

3. $\operatorname{sign}\left(f_{\mathrm{K}^{*}}\right)=-\operatorname{sign}(\alpha)$

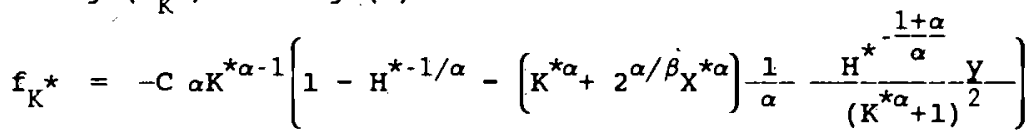

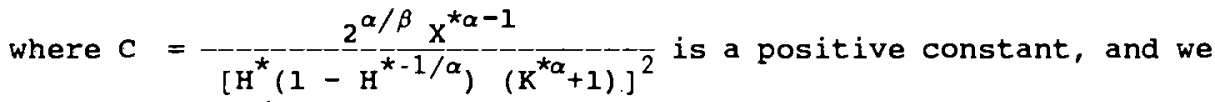
define $y=2^{\alpha / \beta} \mathrm{X}^{\star \alpha}-1$. Notice that the definitions of $\mathrm{Y}$ and of $\mathrm{H}^{*}$ imply:

$$
\mathrm{H}^{\star}=1+\frac{\mathrm{Y}}{\mathrm{K}^{\star \alpha}+1}
$$

Using the above relationship:

$$
\mathrm{f}_{\mathrm{K}}{ }^{*}=-\mathrm{C} \alpha \mathrm{K}^{\star \alpha-1} \mathrm{H}^{\star-1 / \alpha}\left(\mathrm{H}^{\star 1 / \alpha}-1-\frac{\mathrm{H}^{\star}-1}{\alpha}-\right.
$$


We will show that the term in brackets is positive, so that the sign of $\alpha$ determines the sign of the derivative. Call the term in brackets $\Omega$. We have that:

$\Omega=H^{* 1 / \alpha}-1-\frac{2^{\alpha / \beta} \mathrm{x}^{* \alpha}-1}{\alpha\left(\mathrm{K}^{* \alpha}+1\right)}$

For the production function to have the standard properties, the parameter $\beta$ must be constrained to be less than or equal to 1 . Note that for an interior solution to the bargaining problem to exist $x^{*}$ is constrained to be $.5 \leq \mathrm{x}^{*} \leq .5^{1 / \beta}$, because both countries must be in a position superior to their threat points. Therefore, when $\beta=1$, $\mathrm{x}^{\star}=.5$, and $\Omega=0$. Because $\mathrm{d} \Omega / \mathrm{d} \beta<0$, as will be shown below, it follows that for $\beta<1 \Omega$ is positive, and $\mathrm{f}_{\mathrm{K}}$ * has the opposite sign to $\alpha$.

$$
\frac{\mathrm{d} \Omega}{\mathrm{d} \beta}=-\frac{\mathrm{x}^{* \alpha}}{\beta^{2}}-\frac{2^{\alpha / \beta}}{\left(\mathrm{K}^{* \alpha}+\underline{\ln }+\underline{2}-\underline{2}\right.}-\left(\mathrm{H}^{*^{\frac{1-\alpha}{\alpha}}}-1\right)
$$

The negative sign of follows from $\mathrm{H}^{*^{1-\alpha} \alpha}>1$. To show this, notice that $H^{\star 1 / \alpha}>1$ because the debtor has some gains from trade. Thus, when $0<\alpha<1, \mathrm{H}>1$, and the inequality holds. When $\alpha<0$, $\mathrm{H}^{*}<1$ and $\frac{1-\alpha}{\alpha}<0$, so that the inequality also holds. 
2. The Effect of a Change in Endowment on the Creditor's Payoff

For the repayment to the creditor to be higher in the high-endowment state, we need to show that $\mathrm{dx}^{\star} / \mathrm{d} \overline{\mathrm{x}}<1$, that is, that the payoff to the debtor country increases less than one for one. Again, we can express the first order condition as:

$$
\text { (a3) } f\left(x^{*}\right)=g\left(x^{*}, \bar{x}\right)
$$

Inspection of (16) reveals that:

$$
g_{X}{ }^{*}=-g_{\bar{X}}
$$

which implies:

$$
\text { (a4) } \frac{\mathrm{d} \mathrm{x}^{\star}}{\mathrm{d} \overline{\mathrm{X}}}=\frac{\mathrm{g}_{\mathrm{X}^{\star}}}{\mathrm{g}_{\mathrm{X}}^{\star}-\mathrm{f}_{\mathrm{X}}{ }^{\star}}<1 \text {. }
$$




\section{References}

Aizenman, Joshua (1988), "Trade Dependency, Bargaining and External Debt," International Monetary Fund Working Paper WP/88/90.

and Eduardo Borensztein (1988), "Debt and Conditionality under Endogenous Terms of Trade," IMF Staff Papers, 35 No. 4, pP 686-713.

Binmore, Ken (1987), "Perfect Equilibria in Bargaining Models," in $\mathrm{K}$. Binmore and $P$. Dasgupta eds, The Economics of Bargaining, Oxford and New York; Basil Blackwell.

Borensztein, Eduardo and A. Rex Ghosh (1989), "Foreign Borrowing and Export Promotion Policies," International Monetary Fund Working Paper WP/89/15.

Bulow, I. Jeremy, and Kenneth Rogoff (1988), "A Constant Recontracting Model of Sovereign Debt," Journal of Political Economy, 97, pp. 155-78.

Calvo, Guillermo (1989), "A Delicate Equilibrium: Notes on Debt Relief and Default Penalties in an International Context," International Monetary Fund Working Paper WP/89/10.

Corden, W. Max (1988), "Debt Relief and Adjustment Incentives," IMF Staff Papers, 35 No. 4, pp. 628-643.

Diwan, Ishac and Shabtai Donnenfeld (1986), "Trade Policy, Foreign Investment and Potential Expropriation, "Studies in Banking and Finance, 3 , pp 83-96.

Dooley, Michael P. (1986), "An Analysis of the Debt Crisis," International Monetary Fund Working Paper WP/86/14.

Froot, Kennneth (1988), "Buybacks, Exit Bonds, and the Optimality of Debt and Liquidity Relief," NBER Working Paper No, 2675.

Helpman, Elhanan (1988), "Voluntary Debt Reduction: Incentives and Welfare," International Monetary Fund Working Paper WP/88/84.

Krugman, Paul (1988), "Financing vs. Forgiving a Debt Overhang: Some Analytical Notes," National Bureau of Economic Research Working Paper No. 2486.

O'Connell, Stephen (1987), "Reserves and Debt in LDCs," University of Pennsylvania Working Paper No. 5.

Rotemberg, Julio (1988), "Sovereign Debt Buybacks Can Lower Bargaining Costs," National Bureau of Economic Research Working Paper No. 2767. 
Roth, Alvin (1979), Axiomatic Models of Bargaining, Berlin Heidelberg New York: Springer-Verlag.

Sachs, Jeffrey (1988), "Conditionality, Debt Relief, and the Developing Country Debt Crisis," NBER Working Paper No. 2644. 


\section{Figure 1}

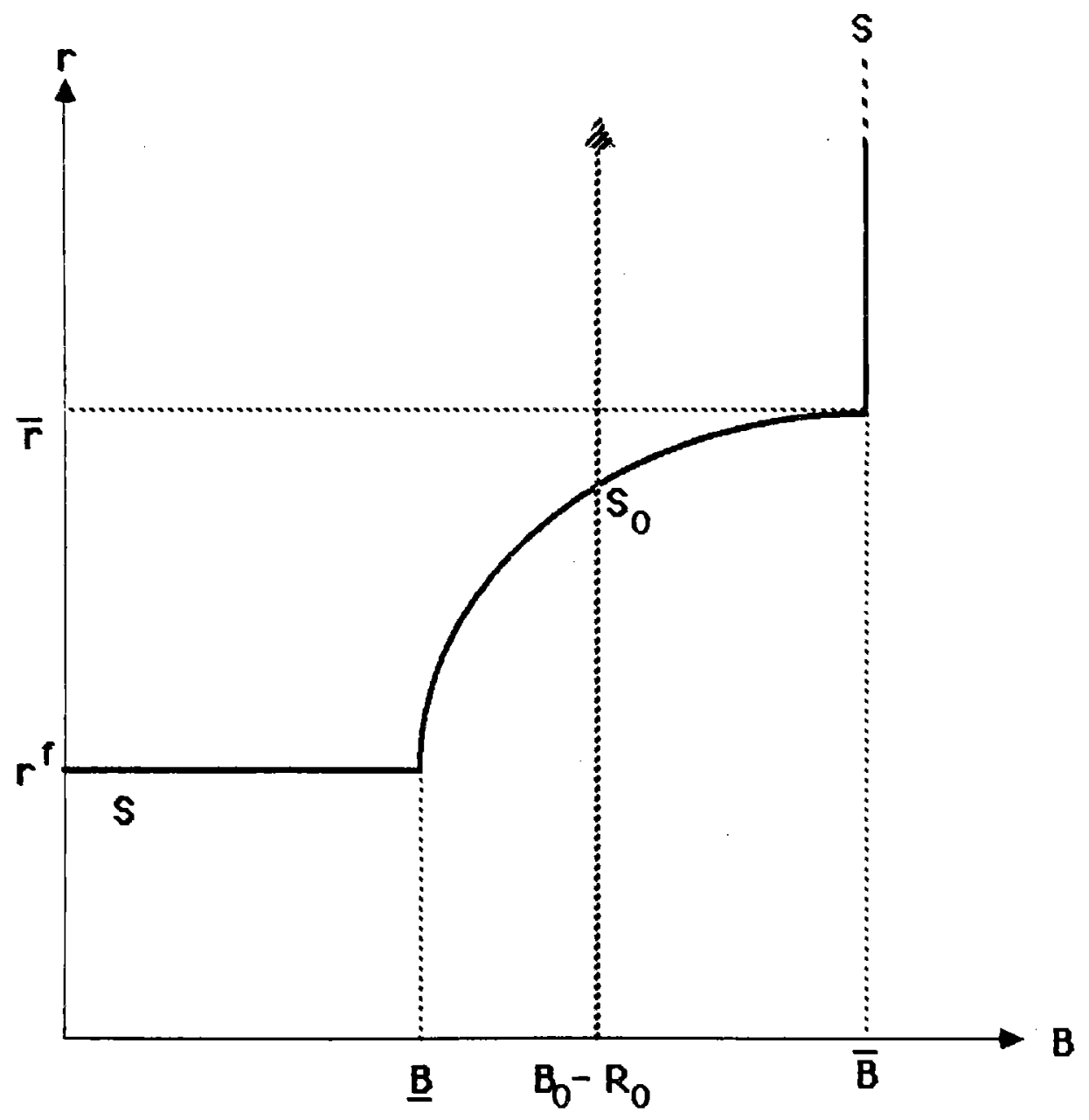




\section{Figure 2}

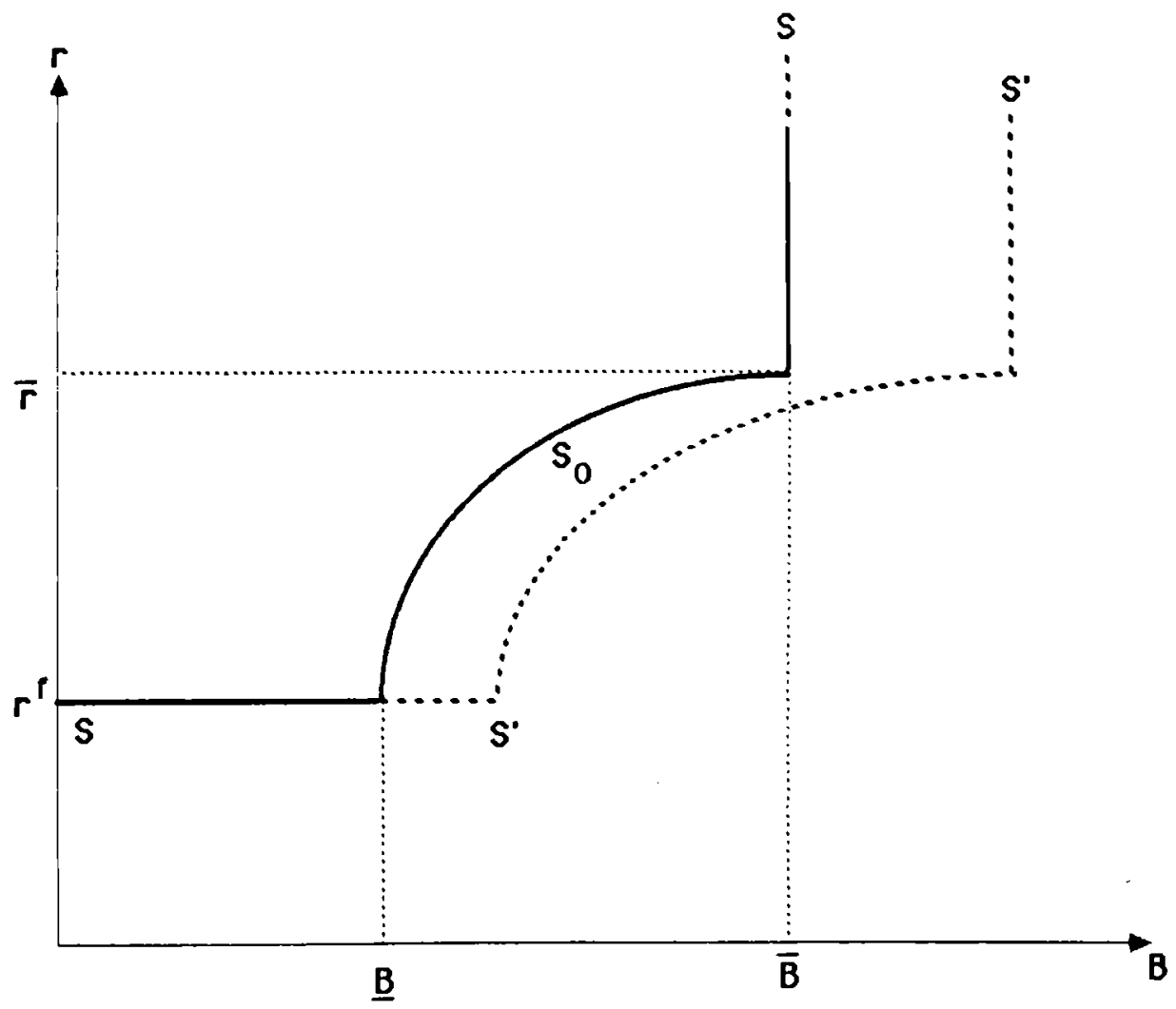

THE CREDIT SUPPLY FUNCTION WITH IN-TIAL OUTSTANDING DEBT 


\section{Figure 3}

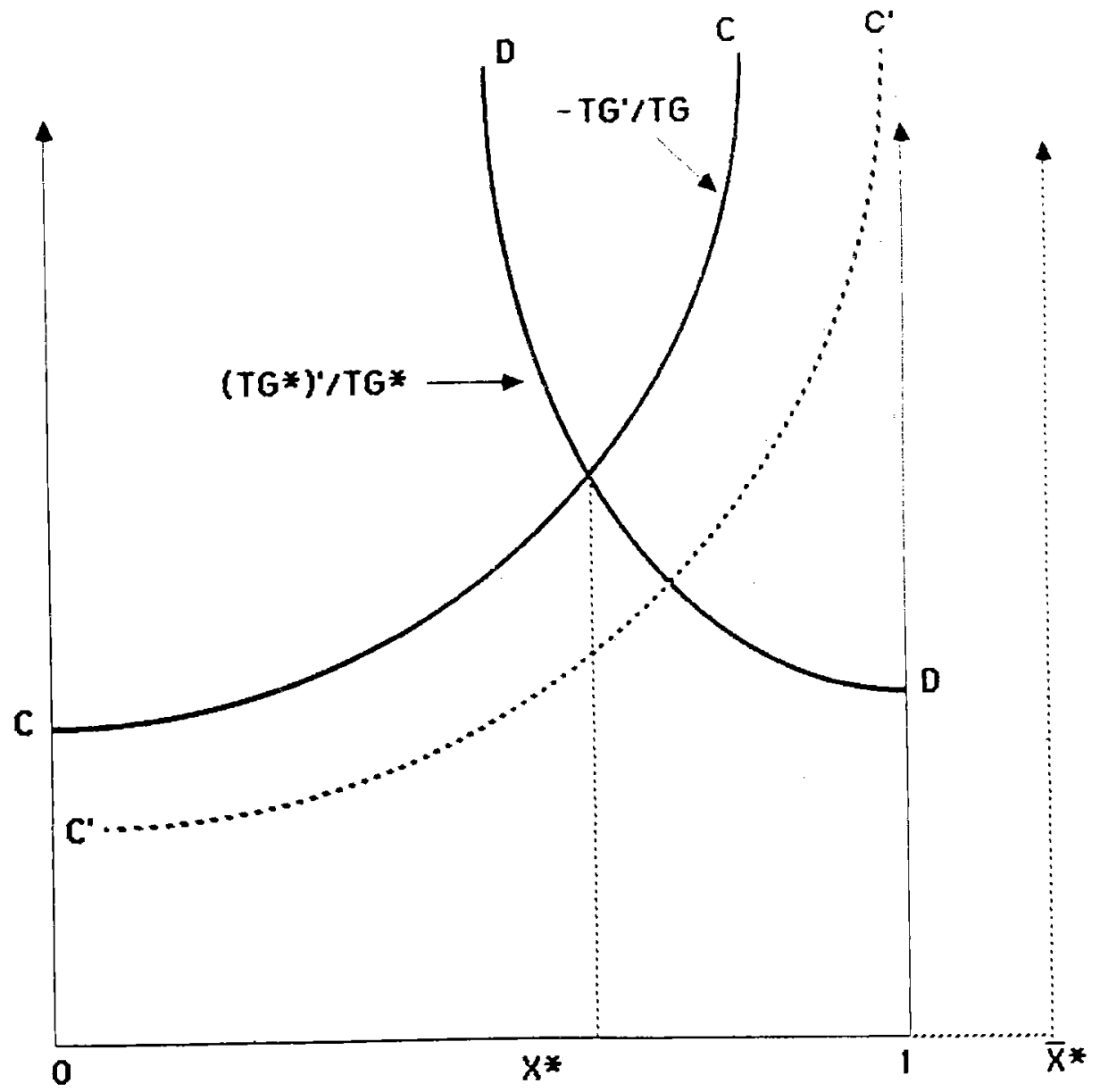

THE BARGAINING EQUILIBRIUM 